\title{
NILAI-NILAI PENDIDIKAN DALAM KISAH NABI AYUB AS., (TAFSIR Q.S. SHAD AYAT 41-44)
}

\author{
Ratu Suntiah \\ Ruslandi \\ Jurusan Pendidikan Agama Islam, \\ UIN Sunan Gunung Djati Bandung \\ ratusuntiah@uinsgd.ac.id
}

\begin{abstract}
Abstrak
Tujuan penelitian ini adalah untuk mengetahui konsep nilai-nilai pendidikan secara umum; pendapat para mufassir tentang Q.S. Shad ayat 41-44 3) Nilai-nilai pendidikan dalam kisah Nabi Ayub As. Penelitian ini menggunakan metode penelitian dan teknik pengumpulan data Library Research serta metode deskriptif Teknik pengumpulan data dokumentasi. Adapun sumber data dokumen yang dapat diperoleh dari lapangan berupa buku, arsip, majalah, serta dokumen-dokumen yang berhubungan dengan fokus penelitian. Berdasarkan hasil penelitian dapat diketahui bahwa nilai merupakan suatu konsep keyakinan seseorang terhadap sesuatu yang dipandang berharga olehnya yang mengarahkan kepada tingkah laku seseorang dalam kehidupannya sehari-hari sebagai makhluk hidup yang bermasyarakat, dan menjadikannya dasar keyakinan dalam bertindak untuk menentukan apakah tindakan itu benar atau salah; Tafsiran Q.S. Shad ayat 41-44 merupakan suatu ikhtilaf para ulama tafsir yang memiliki perbedaan penafsiran terhadap Q.S. Shad ayat 41-44 yang menjabarkan tentang kisah Nabi Ayub As; Nilai Pendidikan yang dapat diambil dari Q.S. Shad ayat 41-44 yakni: penghambaan diri kepada Allah, sikap ketergantungan kepada Allah, Larangan mengingkari janji, serta kesabaran dalam menghadapi ujian.
\end{abstract}

Kata Kunci: Nilai, Pendidikan, Nabi Ayub As, Al-Qur'an 


\section{Pendahuluan}

Allah SWT. telah menceritakan kepada kita beberapa kisah Nabi dan Rasul dalam kitab-Nya agar menjadi panutan serta memperkuat keimanan bagi orang-orang yang beriman. Atas dasar itulah pada diri setiap Nabi dan Rasul Allah, terdapat keteladanan yang dapat diambil oleh setiap umat Islam dalam menempuh cobaan dan rintangan kehidupan dunia fana' dan menuntun manusia keakhirat yang kekal. Terkait nilai-nilai pendidikan, Allah memberikan kekuasaan kepada iblis untuk mebinasakan harta dan keluarga Nabi Ayub As, akan tetapi Allah tidak membenarkan iblis untuk membunuh Nabi Ayub As. iblis menggunakan cuaca yang panas dan gerombolan yang kejam untuk membinasakan Nabi Ayub As. sekujur tubuh nabi Ayub ditimpa penyakit kulit yang busuk. Bila ditinjau dari pendidikan Islam, sejarah nabi Ayub As. tentunya memiliki nilai-nilai pendidikan yang sangat penting bagi pendidikan islam dan sangat penting untuk kita kaji hikmah dari kisah keteladanan akhlaknya.

Nabi Ayub As. merupakan Nabi yang kaya raya, tanahnya berbidang-bidang, keturunannya banyak. Namun hal itu tidak membuatnya sombong apalagi melalaikan ibadahnya kepada Allah SWT. bahkan ketika Nabi ayub As. mendapat ujian dari Allah SWT dengan kehilangan Semua harta bendanya, anak dan keturunannya, serta terserang penyakit kulit yang ganas, hal itu tidak membuatnya meninggalkan Allah SWT. bahkan dengan ujian itu Nabi Ayub As. semakin dekat dengan Allah, karena ia yakin bahwa semua harta benda dan keturunan yang ia miliki hanyalah titipan dari Allah SWT. yang sewaktu-waktu dapat diambil oleh-Nya. (Salim, 1985: 52).

Nilai-nilai pendidikan yang dapat diambil dari kisah Nabi Ayub sangatlah banyak jika kita kaji melalui ayat-ayat Al-Qur'an serta pendapat dari para mufassir, sehingga hikmah dan pesan yang dapat diambil dari kisah Nabi Ayub As. dapat kita amalkan dalam kehidupan sehari-hari, ditengah-tengah kondisi zaman yang sangat sulit. Pentingnya pendidikan akhlak bagi terciptanya kondisi lingkungan yang harmonis diperlukan upaya yang serius untuk menanamkan nilai-nilai tersebut secara intensif.

Allah Tabaraka wa Ta'ala menceritakan tentang seorang hamba dan Rasulnya, Ayub As. dan ujian yang diberikan kepadanya berupa kemudharatan pada tubuh, harta dan anaknya. Ketika penderitaan telah 
berlngsung lama dan kondisinya semakin memprihatinkan, qadar juga telah berakhir dan ajal yang ditentukan telah sempurna, beliaupun berdo'a kepada Rabb semesta alam. Nabi Ayub As. adalah salah satu Nabi dan Rasul yang mempunyai akhlak mulia. Kesabaran kepada Allah SWT. membuatnya semakin dekat dengan Allah SWT. sehingga Allah SWT mengabulkan do'anya sehingga nabi Ayub pun sembuh dari penyakit yang dideritanya serta harta dan keluarganya juga bertambah-tambah dari harikehari sebagaimana sediakala. (Salim, 1985: 53)

\section{Metodologi Penelitian}

Peneltian ini menggunakan pendekatan kualitatif dimana dalam penelitian ini penulis menekankan pada nilai-nilai pendidikan yang terkandung dalam surat Shad ayat 41-44. Menurut Kirk dan Miller sebagaimana dikutio oleh Sudarto (Sudarto, 1995:62) mendefinisikan bahwa penelitian kualitatif adalah tradisi tertentu dalam ilmu pengetahuan sosial yang secara fundamental brgantung pada pengamatan pada manusia dalam kawasannya sendiri berhubungan dengan orang-orang tersebut dalam bahasannya dan peristilahannya. Metode Penelitian yang digunakan dalam penelitian ini adalah metode deskriptifyang tertuju pada pemecahan masalah, diantaranya dengan menuturkan, menganalisis, serta mengklarifikasikan. Selain metode deskriptif digunakan juga jenis penelitian kepustakaan / library research yaitu mengumpulkan data atau karya tulis ilmiah yang bertujuan dengan objek penelitian atau pengumpulan data yang bersifat kepustakaan. Atau telaah yang dilaksanakan untuk memecahkan suatu masalah yang pada dasarnya tertumpu pada penelaahan kritis dan dalam terhadap bahan-bahan pustaka.

Jenis data yang digunakan dalam penelitian ini adalah penelitian kualitatif. Menurut Lexy J. Moleong seperti yang dikutip dari Kirk dan Miller mendefinisikan bahwa metodologi penelititian kualitatifadalah tradisi tertentu dalam ilmu pengetahuan sosial yang secara fundamental bergantung kepada pengamatan manusia dalam kawasannya sendiri dan berhubungan dengan orang-orang tersebut dalam bahasanya dan dalam peristilahannya. Kemudian Bog dan Taylor menjelaskan bahwa "metodologi Kualitatif" sebagai prosedur penelitian yang menghasilkan data deskriptif berupa katakata tertulis atau lisan dari orang-orang dan perilaku yang dapat diamati. (Moleong, 2002: 3). Data tertulis yang diamati, yaitu data tentang nilainilai pendidikan dalam kisah Nabi Ayub As. berdasarkan tafsir Al-Qur'an 
surat Shad ayat 41-44. Dalam hal ini penulis mengumpulkan data skripsi ini dengan mengacu pada sumbersumber kepustakaan seperti Alqur'an dan buku yang mendukung. Sumber data yang digunakan dalam penelitian ini meliputi sumber data primer dan sumber data sekunder. Sumber data primer yakni Al-Qur'an surat Shad ayat 41-44 beserta beberapa buku tafsir antara lain: Tafsir Ibnu Katsir; Tafsir Al-Misbah, dan Tafsir Al-Maraghi.

Adapun sumber data sekunder yakni buku-buku penunjang yang relevan dengan masalah penelitian. Teknik pengumpulan data yang dapat mendukung penulisan ini, yakni dengan mengutip surat Shad ayat 41-44, yang kemudian dijelaskan dengan menggunakan kitab-kitab tafsir yang difokuskan terhadap nilai-nilai pendidikan dalam kisah Nabi Ayub As. Data lainnya diperoleh dari literatur-literatur yang relevan yaitu penulis menggunakan buku-buku yang berkaitan dengan pembahasan sebagai referensi. Dengan teknik pengumpulan data dokumetasi, yaitu proses melihat kembali sumber-sumber data dari dokumen yang ada dan dapat digunakn untuk memperluas data-data yang telah ditemukan. Adapun sumber data dokumen yang dapat diperoleh dari lapangan berupa buku, arsip, majalah, serta dokumen-dokumen yang berhubungan dengan fokus penelitian. Objek penelitian ini adalah nilai-nilai pendidikan. Penulis memfokuskan kajian ini pada nilai-nilai pendidikan yang terkandung dalam kisah Nabi Ayyub yang termaktub dalam Alqur'an Surat Shad ayat 41-44.

\section{Hasil dan Pembahasan}

\section{A. Hasil Penelitian}

1. Penafsiran para Mufassir terhadap Q.S. Shad ayat 41-44

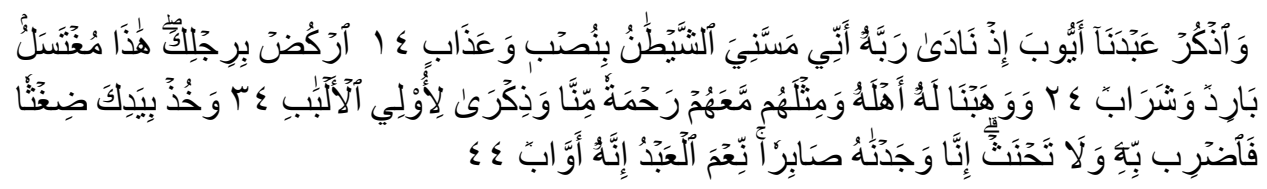

dan ingatlah akan hamba Kami Ayyub ketika ia menyeru Tuhannya: "Sesungguhnya aku diganggu syaitan dengan kepayahan dan siksaan".

(Allah berfirman): "Hantamkanlah kakimu; Inilah air yang sejuk untuk mandi dan untuk minum”. dan Kami anugerahi Dia (dengan mengumpulkan kembali) keluarganya dan (kami tambahkan) kepada mereka sebanyak mereka pula sebagai rahmat 
dari Kami dan pelajaran bagi orang-orang yang mempunyai fikiran. dan ambillah dengan tanganmu seikat (rumput), Maka pukullah dengan itu dan janganlah kamu melanggar sumpah. Sesungguhnya Kami dapati Dia (Ayyub) seorang yang sabar. Dialah Sebaik-baik hamba. Sesungguhnya Dia Amat taat (kepada Tuhan-nya)

a) Menurut Ibnu Katsir dalam Tafsir Ibnu Katsir

Allah SWT menceritakan tentang seorang hamba dan Rasul-Nya Ayyub As, dan ujian yang diberikan kepadanya berupa penderitaan pada tubuh, harta dan anaknya. Ketika Penderitaan telah berlangsung lama dan kondisinya semakin memprihatinkan, qadar juga telah berakhir dan ajal yang ditentukan telah sempurna, beliaupun berdo'a kepada Rabb semesta alam dan Ilah para Rasul:

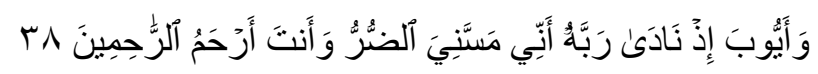

"(Ya Tuhanku), Sesungguhnya aku telah ditimpa penyakit dan Engkau adalah Tuhan yang Maha Penyayang di antara semua Penyayang" (Q.s. Al-Anbiyaa':

Semakna dengan yang disebutkan dengan ayat yang mulia ini Allah Ta'ala berfirman:

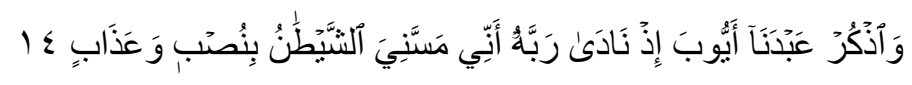

dan ingatlah akan hamba Kami Ayyub ketika ia menyeru Tuhan-nya: "Sesungguhnya aku diganggu syaitan dengan kepayahan dan siksaan".

Satu pendapat mengatakan bahwa kepayahan yang dimaksud adalah penderitaan yang ada pada badan, siksaan pada harta, dan anaknya. Ketika itu, Rabb Yang Mahapenyayang diantara semua penyayang memperkenankannya dan memerintahkannya untuk beranjak dari tempatnya serta menghentakkan tanah dengan kakinya, lalu ia melakukannya. Tibatiba Allah Ta'ala memancarkan mata air memerintahkannya untuk mandi, sehingga hilanglah seluruh penyakit yang diderita tubuhnya. Kemudian Allah memerintahkannya lagi untuk menghentakkan tanah yang lain dengan kakinya, maka muncul pula mata air lain, lalu Dia memerintahkannya untuk 
meminum air itu, hingga hilanglah seluruh penyakit dalam bathinnya, maka sempurnalah kesehatan lahir dan bathinnya.

Untuk itu, Allah berfirman:

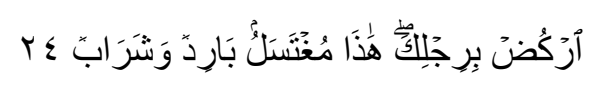

(Allah berfirman): "Hantamkanlah kakimu; Inilah air yang sejuk untuk mandi dan untuk minum".

Biasanya sebelum itu, ketika beliau hendak keluar melakukan buang hajat atau selesai darinya, maka sang istri memegang tangannya sampai ke tempatnya. Namun, pada suatu hari dia terlambat terhadap istrinya, maka Allahmemberikan wahyukepadaAyyub: (Allahberfirman): "Hantamkanlah kakimu; Inilah air yang sejuk untuk mandi dan untuk minum”. Dan ketika sang istri merasakan keterlambatannya, ia pun menengok untuk menegok melihat, tetapi Nabi Ayyub As telah datang menghampirinya dalam keadaan telah disembuhkan Allah dari penyakitnya dan memiliki bentuk yang lebih elok. Ketika istrinya melihatnya, ia berkata: "Semoga Allah memberikan berkah kepadamu. Apakah engkau telah melihat Nabi Allah yang berpenyakitan itu? Demi Allah Yang Mahakuasa untuk melakukan hal itu, aku tidak melihat seorang laki-laki yang lebih mirip dengannya selain dirimu, ketika dia masih sehat". Nabi Ayyub pun berkata: "Akulah dia".

Imam Ahmad meriwayatkan dari hamam bin Munabbih, dari Abu Hurairah Ra. bahwa Rasulullah Saw. bersabda: Untuk itu Allah berfirman: "Disaat Ayyub mandi dalam keadaan telanjang, tiba-tiba jatuhlah seekor belalang dari emas. Lalu Ayyub As. mengantonginya dibajunya, maka Rabb berfirman: 'Hai Ayyub, bukankah Aku telah mencukupimu dari apa yang engkau lihat?' Ayyub As. menjawab:'Betul, ya Rabb-ku. Akan tetapi aku tidak akan merasa cukup dari berkahmu." (Al-Bukhari meriwayatkan hadits ini sendiri dari 'Abdurrazzaq)

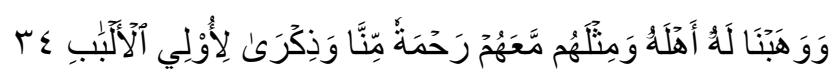

dan Kami anugerahi Dia (dengan mengumpulkan kembali) keluarganya dan (kami tambahkan) kepada mereka sebanyak mereka pula sebagai rahmat dari Kami dan pelajaran bagi orang-orang yang mempunyai fikiran. 
b) Menurut M. Quraish Shihab dalam Tafsir Al-Misbah

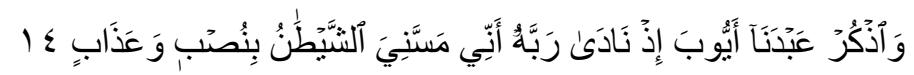

41. dan ingatlah akan hamba Kami Ayyub ketika ia menyeru Tuhan-nya: "Sesungguhnya aku diganggu syaitan dengan kepayahan dan siksaan".

Ayat diatas menyatakan, Dan disamping menarik pelajaran dari kisah Nabi Sulaiman, maka ingat dan tarik jugal-lah pelajaran dari kisah hamba Kami Ayub. Yaitu, ketika ia menyeru, yakni bermohon kepada Allah SWT., Tuhannya bahwa: "Sesunguhnya aku yang merupakan salah seorang hamba-Mu telah disentuh oleh setan dengan kepayahan, penyakit, dan kesulitan siksaan, yakni rasa sakit yang menghalau seluruh kelezatan."

Nabi Ayub As. dalam ucapannya di atas tidak menggerutu tidak juga menyatakan bahwa apa yag dideritanya bersumber dari Allah, tetapi dari setan. Demikian beliu tidak menisbatkan sesuatu yang buruk kepadaNya. Disamping itu, walaupun apa yang beliau derita itu cukup berat, sebagaimana diisyaratkan oleh bentuk nakirah/indefinite pada kata (نصب) nuhb dan (عذاب) 'adzab, beliau melukiskannya sebagai (مسّني) massani/aku telah disentuh bukan telah ditimpa.

Penggunaan kata setan oleh Nabi Ayub dalam ucapannya itu bukan kata iblis yang dari segi bahasa mengandung makna keputusasaan, memberi kesan bahwa beliau sama sekali tidak berputus asa atas rahmat Allah. Demikian Al-Biqa'i. Ibn 'Asyur menulis bahwa redaksi ayat di atas menjadikan pelaku penyentuh siksa dan kepayahan itu adalah setan. Ini menurutnya tidak sejalan dengan apa yang secara umum diketahui yakni bahwa pengaruh setan hanya terbatas pada merayu dan mencampakkan bisikan-bisikan negatif kepada manusia, bukan penyebab penyakit atau kepayahan. Atas dasar itu, Ibn 'Asyur mengemukakan bahwa yang dimaksud oleh ayat di atas adalah bahwa setan tidak menyentuhnya dengan godaan dan bisikan-bisikan negatif yang disebabkan oleh kepayahan dan siksa yang sedang dialaminya. Jadi, bukan setan yang mengakibatkan kepayahan dan siksaan itu, tetapi kepayahan dan siksaan itu dijadikan setan sebagai dalih untuk menanamkan bisikan negatif berupa prasangka buruk terhadap Allah SWT., bisa juga huruf ba pada kata (بنصب) binushbin dalam arti bersama yakni, yakni aku disentuh oleh bisikan negatif setan bersama dengan kepayahan dan siksaan. Demikian lebih kurang tulis ulama itu. 
Ketika menafsirkan Q.S. Ash-Shaffat: 65 penulis kemukakan bahwa sesuatu yang tidak menyenangkan pun dinamai setan dan tidak harus kata tersebut selalu dipahami dalam arti sosok makhluk halus. Al-Qur'an tidak menjelaskan apa bentuk kepayahan dan siksa yang dialami oleh Nabi Ayub. Ulama berpendapat bahwa hal tersebut berkaitan dengan penyakit fisik. Sebagian ulama melukiskannya sedemikian parah sehingga daging beliau berguguran dan keluarga beliau meninggalkannya. Pendapat ini rasanya sangat berlebihan dan tanpa dasar yang dapat dipertanggungjawabkan. Apalagi seorang Nabi tentulah seorang yang memiliki penampilan yang simpatik, dan kalaupun sesekali menderita penyakit, itu bukanlah yang menjijikan. Bagaimana mungkin seorang Nabi berpenampilan buruk atau menderita penyakit yang menjadikan orang menjauhinya, padahal ia dituntut untuk meraih simpati masyarakatnya.

Nabi Ayub dalam doanya diatas menyampaikan keluhan beliau dengan sangat singkat. Beliau hanya menyebut kepayahan dan siksa. Ini mengisyaratkan bahwa apa yang beliau alami tidak menyentuh kecuali diri beliau sendiri. Harta benda dan keluarga beliau tetap dalam keadaan utuh tidak kurang dari suatu apapun. Jika dipahami demikian, itu tidak sejalan dengan informasi banyak riwayat.

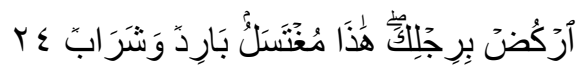

42. (Allah berfirman): "Hantamkanlah kakimu; Inilah air yang sejuk untuk mandi dan untuk minum".

Mendengar permohonan dan keluhan Nabi Ayub As. yang terekam oleh ayat lalu, Allah berfirman menyambutnya bahwa: 'Hentakkanlah kedua kakimu ke bumi niscaya akan memancar air. Maka dia pun menghentakkannya sehingga air memancar dan ketika itu Allah "Inilah air yang sejuk untuk engkau gunakan mandi dan untuk engkau minum sehingga kepayahan serta rasa sakitmu akan segera hilang.

Sesungguhnya Nabiyullah Ayub As. mengalami cobaannya selama 18 tahun. Ketika itu, ia ditolak oleh kerabatnya yang dekat maupun yang jauh, kecuali dua orang lelaki yang merupakan saudaranya yang paling kental. Kedua orang itu datang padanya pagi dan petang. Seorang diantaranya berkata kepada yang lain: Ketahuilah, demi Allah sesungguhnya Ayub telah melakukan suatu dosa yang tak pernah dilakukan oleh seorangpun di 
antara seluruh alam. Maka kawannya bertanya: Apa itu? Dijawab: sejak 18 tahun Allah Ta'ala tidak merahmatinya, sehingga ia tidak menghilangkan penyakit yang dia alami. Ketika kedua orang itu datang kepada Ayub, maka laki-laki yang mendengar tuduhan terhadap Ayub tadi tidak tahan lalu menceritakan hal itu kepadanya. Maka berkatalah Ayub: Aku tidak tahu apa yang kamu katakan itu, hanya saja Alah Azza wa Jalla tahu bahwa aku pernah lewat kepada dua orang yang tengah bertengkar, lalu keduanya menyebut-nyebut nama Allah Ta'ala. Maka akupun langsung kerumah lalu aku membayar kifarat dari keua orang itu karena aku tidak suka. Maka, Allah Ta'la disebut-sebut hanya dengan cara yang haq.

Tidak diragukan bahwa hadis ini termasuk Ahad yang bertentangan dengan prinsip-prinsip agama yang benar. Yatu, bahwa para nabi pasti tidak ditimpa penyakit-penyakit yang membuat orang lari dari mereka. Karena tuga mereka adalah menyampaikan risalah yang dia utus dengannya kepada umat manusia. Maka bagaimana umat dapat berhimpun disekelilingnya dan bagaimana para nabi dapat berbicara kepada mereka apabila keadaannya demikian dan mengalami cobaan seperti itu. Oleh karena itu dalam menghadapi berita-berita seperti ini, kita harus bersikap waspada dan berhati-hati dalam menerimanya, atau kita pastikan bahwa berita seperti itu tidaklah benar, karena bertentagan dengan sesuatu yang tegas (qat'i) yang tidak diragukan lagi.

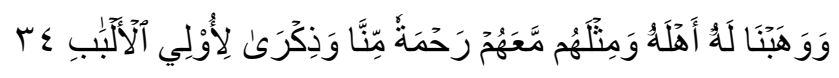

43. dan Kami anugerahi Dia (dengan mengumpulkan kembali) keluarganya dan (kami tambahkan) kepada mereka sebanyak mereka pula sebagai rahmat dari Kami dan pelajaran bagi orang-orang yang mempunyai fikiran. dan kami kumpulkan untuk Ayub keluarganya setela tercerai berai dan berpisahpisah, dan kami perbanyak keturunannya, sehingga mereka menjadi dua kali lipat dari semula, sebagai rahmat dari Kami dan peringatan bagi orangorang yang mempunyai akal sehat, agar kita dapat mengambil pelajaran dan mengetahui bahwa rahmat itu dekat kepada orang-orang yang berbuat baik, dan bahwa beserta kesusahan terdapat kemudahan dan manusia itu tidak boleh putus asa terhadap dibukanya jalan keluar, setelah mengalami kesusahan. 
Sesungguhnya Kami dapati Ayub sebagai orang yang sabar atas penderitaan yang menimpa dirinya maupun keluarga dan hartanya. Maka kami memberikan balasan berupa dilepaskannya ia dari kesusahan dan dihilangkan penderitaannya. Mengadu kepada Allah bukanlah mengurangi kesabaran dan sedikitpun tidak memuat arti kegusaran, mengadu kepada Allah adalah seperti orang yang menginginkan kesentausaan dan meminta kesembuhan.

\section{Makna Kalimat Q.S. Shad ayat 41-44}

\section{Tabel. Makna Q.S. Shad ayat 41}

\begin{tabular}{|l|l|l|}
\hline No. & Kitab/Mufassir & Arti \\
\hline 1 & $\begin{array}{l}\text { Tafsir Ibnu Katsir, Abu } \\
\text { Al Fida Muhammad Ali } \\
\text { Ashobuni }\end{array}$ & $\begin{array}{l}\text { Dan ingatlah akan hamba Kami Ayyub ke- } \\
\text { tika ia menyeru Tuhannya, "Sesungguhn- } \\
\text { ya aku diusap setan dengan kepayahan } \\
\text { dan siksaan". }\end{array}$ \\
\hline 2 & $\begin{array}{l}\text { Tafsir Al-Misbah/ M. Man ingatlah hamba Kami Ayyub ketika } \\
\text { Quraish Shihab }\end{array}$ & $\begin{array}{l}\text { la menyeru Tuhannya Sesungguhnya aku } \\
\text { telah disentuh oleh setandengan kepayah- } \\
\text { an dan siksaan." }\end{array}$ \\
\hline 3 & $\begin{array}{l}\text { Al-Maraghi/Ahmad Musta- } \\
\text { fa Al-Maraghi }\end{array}$ & $\begin{array}{l}\text { Dan ceritakanlah kepada kaummu tentang } \\
\text { kesabaran nabi Ayyub ketika ia berseru } \\
\text { kepada Tuhannya dengan mengatakan, } \\
\text { "Tuhanku, sesungguhnya aku telah ditim- } \\
\text { pa penyakit dan keluargaku telah tercerai } \\
\text { berai, sedang anakku telah musnah". }\end{array}$ \\
\hline
\end{tabular}

Tabel diatas menjelaskan tentang kisah nabi Ayyub yang pada dulunya kehidupan nabi Ayyub sejahtera dan penuh dengan kekayaan turunan anak-anaknya banyak hartanya melipah dan penuh dengan kesenangan, akan tetapi pada suatu hari setan menggodanya atas izin Allah Ayyub tetap bersabar dan tabah menerima cobaan silih berganti mulai dari sakit, kehilangan anak, dan martabat.

Tabel 2. Makna Q.S. Shad ayat 42

\begin{tabular}{|l|l|l|}
\hline No. & Kitab/Mufassir & Arti \\
\hline 1 & $\begin{array}{l}\text { Tafsir Ibnu Katsir, Abu } \\
\text { Al Fida Muhammad Ali } \\
\text { Ashobuni }\end{array}$ & $\begin{array}{l}\text { Hatamkanlah kakimu: inilah air yang } \\
\text { sejuk untuk mandi dan untuk minum. }\end{array}$ \\
\hline 2 & $\begin{array}{l}\text { Tafsir Al-Misbah/ M. M. } \\
\text { Quraish Shihab }\end{array}$ & $\begin{array}{l}\text { Hentakkanlah kakimu; inilah air yang } \\
\text { sejuk untuk mandi dan untuk minum. }\end{array}$
\end{tabular}


3

Al-Maraghi/Ahmad Mustafa Al-Maraghi
Gerakanlah tanah dengan kakimu dan pukullah dengan kakimu itu, niscaya ia mengeluarkan suatu sumber air yang dapat kamu gunakan untuk mandi dan minum, sehingga kamu dapat sembuh dari penyakit yang kamu alami.

Tabel diatas menjelaskan tentang anugerah yang Allah berikan kepada Nabi Ayyub berupa kesembuhan dari penyakit dengan meminum air yang sejuk dari tanah lalu menggunakannya untuk mandi yang merupakan hasil dari kesabaran.

Tabel 3.Makna Q.S. Shad ayat 43

\begin{tabular}{|l|l|l|}
\hline No. & Kitab/Mufassir & Arti \\
\hline 1 & $\begin{array}{l}\text { Tafsir Ibnu Kat- } \\
\text { sir, Abu Al Fida } \\
\text { Muhammad Ali } \\
\text { Ashobuni }\end{array}$ & $\begin{array}{l}\text { Dan Kami Anugrahi kembalian dia keluarga dan } \\
\text { kami tambah-kan kepada mereka sebanyak mer- } \\
\text { eka pula sebagai rahmat dari kami dan pelajaran } \\
\text { bagi orang-orang yang mempunyai pikiran. }\end{array}$ \\
\hline 2 & $\begin{array}{l}\text { Tafsir Al-Misbah// } \\
\text { M. Quraish Shihab }\end{array}$ & $\begin{array}{l}\text { Dan Kami menganugerahi untuknya keluarganya } \\
\text { dan sebanyak mereka itu pula bersama mereka } \\
\text { sebagai rahmat dari Kami serta pelajaran bagi } \\
\text { orang-orang yang mempunyai pikiran cerah }\end{array}$ \\
\hline 3 & $\begin{array}{l}\text { Al-Maraghi/Ah- } \\
\text { mad Mustafa Al- }\end{array}$ & $\begin{array}{l}\text { Dan Kami kumpulkan untuk Ayyub keluargan- } \\
\text { ya setelah tercerai berai dan berpisah-pisah, dan } \\
\text { kami perbanyak keturunannya, sehingga mereka } \\
\text { menjadi dua kali lipat dari semula, sebagai rah- } \\
\text { mat dari kami dan peringatan bagi orang-orang } \\
\text { yang mempunyai akal sehat. }\end{array}$ \\
\hline
\end{tabular}

Tabel diatas menjelaskan tentang pelajaran yang diberikan dari Allah swt bahwasanya Allah maha besar apa yang dia kehendaki pastilah jalan yang terbaik Ayyub bersabar karana Ayyub percaya apa yang ditakdirkan oleh Allah swt kepada hambanya adalah yang terbaik.

Tabel 4.Makna Q.S. Shad ayat 44

\begin{tabular}{|l|l|l|}
\hline No. & Kitab/Mufassir & Arti \\
\hline \multirow{1}{*}{1} & $\begin{array}{l}\text { Tafsir Ibnu Kat- } \\
\text { sir, Abu Al Fida } \\
\text { Muhammad Ali } \\
\text { Ashobuni }\end{array}$ & $\begin{array}{l}\text { Dan ambilah dengan tanganmu seikat, maka pukul- } \\
\text { lah dengan itu dan janganlah kamu melanggar sump- } \\
\text { ah. Sesungguhnya Kami dapati dia seorang yang sa- } \\
\text { bar. dialah sebaik-baiknya hamba.Sesungguhnya dia } \\
\text { amat taat. }\end{array}$ \\
\hline
\end{tabular}




\begin{tabular}{|l|l|l|}
\hline 2 & $\begin{array}{l}\text { Tafsir Al-Misbah/ } \\
\text { M. Quraish Shihab }\end{array}$ & $\begin{array}{l}\text { Dan ambillah dengan tanganmu seikat rumput, } \\
\text { maka pukullah dengannya dan janganlah melang- } \\
\text { gar sumpah. Sesungguhnya Kami mendapatinya } \\
\text { seorang penyabar. Dialah sebaik baiknya hamba. } \\
\text { Sesungguhnya dia selalu kembali }\end{array}$ \\
\hline 3 & $\begin{array}{l}\text { Al-Maraghi/Ah- } \\
\text { mad Mustafa ambilah seikat kecil tumbuhan yang berbau } \\
\text { Al-Maraghi }\end{array}$ & $\begin{array}{l}\text { Darum atau rumput, lalu pukulkanlah ia. Dengan } \\
\text { demikian, tertebuslah sumpah-mu yang telah kamu } \\
\text { ucapkan. Dalam pada itu, al-Quran tidak menerang- } \\
\text { kan kepada kita atas dasar apakah ayyub bersumpah } \\
\text { dan terhadap siapakah sumpahnya dia ucapkan. }\end{array}$ \\
\hline
\end{tabular}

Tabel 4 menjelaskan kemurahan Allah member jalan keluar bagi kaum yang bersabar dan berjasa yang dicerikan istri Nabi Ayyub, Rahmah yang taat menemani beliau akan tetapi terkena godaan setan melihat taatnya Rahma keapda Ayyub maka Allah mengampuni dan meringankan hukumannya. Berdasarkan uraian tafsiran para mufasir tentang Q.S Shaad 41-44 maka dirangkum sebagai berikut :

1) Bersabar atas ketetapannya dan berdoa, mengadu kepada Allah bukanlah berarti mengurangi kesabaran dan sedikit pun tidak memuat arti kegusaran.mengadu kepada Allah adalah seperti orang yang menginginkan kesentuasaan dan meminta kesembuhan seperti yang di kisahkan dalam cerita nabi Ayyub yang kemudian itu dipuji Tuhanlah, Ayyub dengan suatu pujian dan penghargaan yang tinggi.

2) Sabar ditimpa kemiskinan sesudah kaya, sabar ditimpa kesepian sudah ramai anak-anak dan istri dan sabar menderita penyakit badan dan semuanya itu bertahun-tahun.Dia Besabar sebab dia percaya kepada Allah. Dia percaya bahwa keadaan tidak akan begitu terusmenerus.

3) Anugerah yang dicapai nabi Ayyub itu adalah sebagai rahmat dan kasih sayang dari kami serta pelajaran bagi orang-orang yang mempunyai pikiran yang cerah agar mereka tahu bahwa kesabaran membuahkan kemenangan.Yang terpenting dalam pemaparan kisah-kisah di sinih adalah penggambaran rahmat Allah dan anugrah-Nya kepada hamba-hamba Nya yang Dia berikan cobaan kemudian mereka merasa ridha terhadap takdir-Nya. 
4) Kisah nabi Ayyub merupakan simbol kelapangan dan jalan keluar bagi orang yang bertaqwa serta bertobat kepadanya. Karena Allah swt berfirman, "Kami dapati dia seorang yang sabar. Dialah sebaikbaik hamba. Sesungguhnya dia amat taat."Yaitu, dia menyakini betul bahwa dia milik Tuhannya dan akan kembali kepada Tuhannya, dan selalu bertobat.

\section{B. Pembahasan}

Di dalam Q.S. Shad ayat 41-44 yang telah dikemukakan oleh para mufassir diatas, terkandung beberapa :

1. Penghambaan diri terhadap Allah

Hal ini dibuktikan dengan lafal عبدنا yang artinya menghamba. Manusia diciptakan oleh tidak lain hanya untuk beribadah kepada Allah. Firman Allah dalam surat Ad-Dzariyat ayat 56 berbunyi:

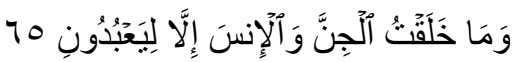

dan aku tidak menciptakan jin dan manusia melainkan supaya mereka mengabdi kepada-Ku.

Dalam firman Allah di atas dijelaskan bahwa Allah menciptakan manusia dan jin untuk beribadah kepada Allah bukan untuk menyembah kepada selain Allah. Karena Tuhan yang berhak disembah hanyalah Allah. Wujud menghamba kepada Allah adalah melakukan semua perintah-Nya dan menjauhi larangan-Nya, seperti melakukan rukun Islam yaitu syahadat, sholat, zakat, dan haji. Selain itu untuk menjadi seorang hamba yang kaffah atau sempurna seseorang harus melalui beberapa jalan di antaranya:

\section{1) Taubat}

Taubat berakar dari kata taba yang berarti kembali. Orang yang bertaubat kepada Allah adalah orang yang kembali dari segala sesuatu, kembali dari sifat-sofat yang tercela menuju sifat yang terpuji, kembali dari larang Allah menuju ke petintah-Nya (Ilyas, 1999: 57). Taubat adalah kembali dari segala sesuatu yang tercela kepada segala sesuatu yang terpuji. Taubat merupakan prinsip pokok dalam kegiatan spiritual para sufi, kunci kebahagian bagi para murid dan syaarat sahnya perjalanan menuju Allah (Isa, 2005: 194). 


\section{2) Ikhlas}

Ikhlas berasal dari kata khalasha dengan arti bersih, jernih, murni. Ikhlas adalah beramal semata-mata mengharap ridha dari Allah atau berbuat tanpa pamrih. Dalam beribadah ada tiga unsur keikhlasan yaitu niat yang ikhlas, beramal dengan sebaik-baiknya, dan pemanfaatan hasil usaha dengan tepat (Ilyas, 1999: 32). Allah memerintahkan kepada umatnya untuk beribadah kepada Allah dengan penuh keikhlasan dan lxxi beramal semata-mata mengharap ridho dari Allah. Ikhlas juga memperingatkan manusia agar jangan sampai tujuan dari ibadahnya adalah untuk meraih penghargaan dan pujian dari manusia.

\section{3) Syukur}

Menurut Sayyid (Isa, 2005: 267) syukur adalah mempergunakan semua nikmat yang telah diberikan Allah, berupa pendengan, penglihatan dan lainnya sesuai dengan tujuan penciptaannya. Manusia diperintahkan untuk bersyukur kepada Allah bukan untuk kepentingan Allah sendiri, tapi untuk kepentingan manusia sendiri (Ilyas, 1999: 53).

\section{Sikap ketergantungan kepada Allah bukan kepada makhluk}

Hal ini dibuktikan dengan lafal vدانذا هبّر yang artinya menyeru kepada Tuhannya. Ketika Nabi Ayyub diuji oleh Allah dengan berbagai cobaan, Nabi Ayyub menggantungkan semuanya kepada Allah, beliau tidak meminta pertolongan kepada selain Allah. Terbukti bahwa dalam ayat Nددانذا هبّر, Nabi Ayyub menyebut Allah dalam do'anya tersebut. Allah merupakan tempat bergantung semua makhluk. Tidak ada yang dapat menandingi kekuasaan Allah dalam memperoleh apapun. Allah Ta'ala sendiri mensifati diri-Nya sebagai tempat bergantung segala sesuatu. Dalam Alqur'an surat Al-Ikhlas ayat 2:

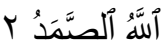

3. Allah adalah Tuhan yang bergantung kepada-Nya segala sesuatu.

Oleh sebab itu, sebaiknya kita menghindarkan diri dari berbagai hal yang menjerumuskan kita pada apa yang disebut dengan kemusyrikan. Serahkan semua permasalahan kepada Allah, memohon kepada-Nya, banyakbanyak berdoa. Dengan demikian kehidupan kita akan mendapat banyak keberkahan (Zainudin, 2012:114). Bila benar-benar telah bergantung kepada Allah, maka akan menyadari, bahwa Allah yang lebih berkuasa dari segalanya. 
Allah lah yang menggenggam dunia dan akhirat. Jadi bila telah menyadari dan menerapkan keyakinan tersebut dalam hidup, maka Allah akan memberikan pertolongan dan perlindungan-Nya. Kekuatan Allah yang akan menolong, karena Allah Maha Mengetahui, Maha Kuasa atas segala sesuatu. Hidup, pekerjaan, lingkungan, semua berada dalam pantauan Allah.

\section{Larangan mengingkari janji}

Hal ini dibuktikan dengan lafal ثنحت الو yang artinya jangan melanggar sumpah. Dalam Islam menepati janji baik hal yang kecil maupun yang besar merupakan kewajiban, karena janji merupakan hutang yang harus dilunasi. Janji adalah ketetapan yang dibuat oleh diri kita sendiri dan untuk dilaksanakan oleh kita sendiri baik itu janji terhadap Allah maupun orang lain (Al-Gazali, 1985: 161).

Keharusan menepati janji apabila berjanji dan hendaknya mereka yang telah berjanji senantiasa menepati atau menunaikan janjinya tersebut pada waktu yang sudah dijanjikan. Dan dari ayat di atas juga telah jelas bahwa janji yang telah diucapkan harus ditepati, karena semuanya akan dimintai pertanggungjawaban di akhirat kelak. Jika kita mengingkari janji yang telah diucapkan berarti kita telah berbuat khianat. Khianat merupakan perbuatan keji yang dibenci Allah. Menepati janji merupakan kewajibanseorang muslim, berdosa apabila menyalahi, baik janji melalui lisan ataupun tulisan, bahkan melanggar janji itu salah satu tanda orang munafik. Dalam Al Qur'an surat Al Maidah ayat 1 Allah berfirman:

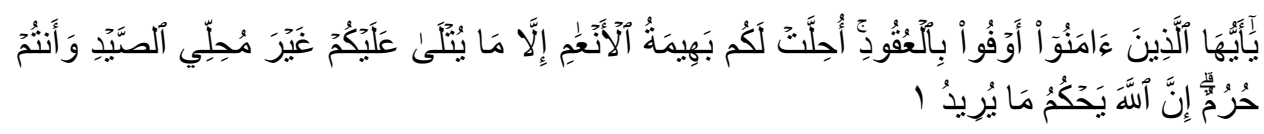

Hai orang-orang yang beriman, penuhilah aqad-aqad itu[388]. Dihalalkan bagimu binatang ternak, kecuali yang akan dibacakan kepadamu. (yang demikian itu) dengan tidak menghalalkan berburu ketika kamu sedang mengerjakan haji. Sesungguhnya Allah menetapkan hukum-hukum menurut yang dikehendaki-Nya.

Nabi Ayyub juga mempunyai janji ketika beliau dalam keadaan sakit parah. Dia bersumpah akan memukul istrinya sebanyak 100 kali pukulan karena telah meninggalkannya dalam keadaan sakit. Tetapi setelah sembuh Nabi Ayyub tidak tega melakukan hal tersebut karena mengingat 
pengorbanan istrinya yang selalu merawat dan mengasihinya ketika beliau sedang sakit. Ketegasan dalam menepati janji, menjalankan amanah adalah merupakan sebuah simbol kesempurnaan kepribadian muslim sejati, baik dan disenangi serta tanda adanya peningkatan sebuah prestasi. Namun jika seandainya ada sesuatu hal yang tidak bisa ditinggalkan, maka sebaiknya janji tersebut dibatalkan atau diubah waktunya sehingga tidak terjadi kesalahpahaman nantinya. Apabila kita tidak bisa memastikan sesuatu hal atau perkara dengan pasti maka hendaklah mengucapkan kata insya Allah.

Kesabaran dalam menghadapi ujian

Hal ini dibuktikan dengan lafal صابر yang artinya orang yang sabar. Sabar merupakan kunci dalam segala urusan didunia ini, Allah SWT., berfirman dalam Q.S. Al-Baqarah ayat: 153 yang berbunyi:

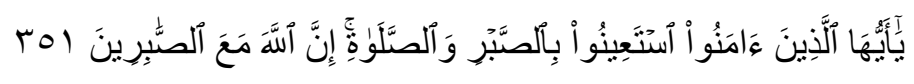

153. Hai orang-orang yang beriman, Jadikanlah sabar dan shalat sebagai penolongmu, Sesungguhnya Allah beserta orang-orang yang sabar.

Setiap orang di dunia ini mempunyai masalah yang berbeda-beda, akan tetapi masalah apapun itu merupakan pemberian Allah untuk semua makhluknya. Allah memberikan ujian kepada manusia dalam bentuk yang berbeda-beda, ujian yang diberikan kepada manusia ada yang menganggap sebagai masalah tetapi ada juga yang menganggap ujian tersebut sebagai suatu nikmat dari Allah SWT.

Dalam menyikapi masalah tersebut, ada yang justru bertambah ketaqwaannya kepada Allah,ada juga yang semakin jauh kepada Allah. Mereka yang menganggap masalah tersebut sebagai rahmat dari Allah, akan senantiasa mendekatkan diri kepada Allah karena menganggap ujian tersebut merupakan bukti kasih sayang Allah kepada hambanya. Tetapi mereka yang menganggap masalah tersebut sebagai ujian dari Allah sering kali berfikir pendek karena tidak sanggup melewatinya. Padahal setiap Allah memberikan ujian kepada hambanya, Allah telah mengukur kemampuan hambanya masing-masing. Satu sikap yang penting dalam menjaga iman adalah sabar. Kesabaran merupakan pengokoh segala urusan di dunia. Abdullah bin Alawy Al-Haddad Al-Husaini menyatakan dalam bukunya yang berjudul Sentuhan-Sentuhan Sufistik Penuntun Jalan Akhirat 
bahwasanya kesabaran merupakan pengokoh segala urusan di dunia ini, kesabaran merupakan suatu akhlaq yang mulia (Anwar, 1999:185).

\section{Simpulan}

Berdasarkan hasil penelitian tentang nilai-nilai pendidikan dalam kisah Nabi Ayub (Tafsir Q.S. Shad ayat 41-44), penulis dapat menyimpulkan sebagai berikut: Konsep nilai-nilai pendidikan secara umum merupakan suatu konsep keyakinan seseorang terhadap sesuatu yang dipandang berharga olehnya yang mengarahkan kepada tingkah laku seseorang dalam kehidupannya sehari-hari sebagai makhluk hidup yang bermasyarakat, dan menjadikannya dasar keyakinan dalam bertindak untuk menentukan apakah tindakan itu benar atau salah; Tafsiran Q.S. ayat 41 menjelaskan tentang kisah nabi Ayyub yang pada dulunya kehidupan nabi Ayyub sejahtera dan penuh dengan kekayaan turunan anak-anaknya banyak hartanya melipah dan penuh dengan kesenangan, akan tetapi pada suatu hari setan menggodanya atas izin Allah Ayyub tetap bersabar dan tabah menerima cobaan silih berganti mulai dari sakit, kehilangan anak, dan martabat.Tafsiran Q.S. Shad ayat 42 menjelaskan tentang anugerah yang Allah berikan kepada Nabi Ayyub berupa kesembuhan dari penyakit dengan meminum air yang sejuk dari tanah lalu menggunakannya untuk mandi yang merupakan hasil dari kesabaran.

Tafsiran Q.S. Shad ayat 43 menjelaskan tentang pelajaran yang diberikan dari Allah swt bahwasanya Allah maha besar apa yang dia kehendaki pastilah jalan yang terbaik Ayyub bersabar karana Ayyub percaya apa yang ditakdirkan oleh Allah swt kepada hambanya adalah yang terbaik. Tafsiran Q.S. ayat 44 menjelaskan kemurahan Allah member jalan keluar bagi kaum yang bersabar dan berjasa yang dicerikan istri Nabi Ayyub, Rahmah yang taat menemani beliau akan tetapi terkena godaan setan melihat taatnya Rahma keapda Ayyub maka Allah mengampuni dan meringankan hukumannya. Nilai-nilai pendidikan dalam Q.S Shad ayat 41-44 Penghambaan diri terhadap Allah, Allah menciptakan manusia dan jin untuk beribadah kepada Allah bukan untuk menyembah kepada selain Allah. Karena Tuhan yang berhak disembah hanyalah Allah. Wujud menghamba kepada Allah adalah melakukan semua perintah-Nya dan menjauhi larangan-Nya, seperti melakukan rukun Islam yaitu syahadat, sholat, zakat, dan haji. Sikap ketergantungan Kepada Allahmemberikan pertolongan dan perlindungan-Nya. Kekuatan Allah yang akan menolong, 
karena Allah Maha Mengetahui, Maha Kuasa atas segala sesuatu. Hidup, pekerjaan, lingkungan, semua berada dalam pantauan Allah. Larangan mengingkari janji yang meski kita jauhi, menepati janji baik hal yang kecil maupun yang besar merupakan kewajiban, karena janji merupakan hutang yang harus dilunasi. Janji adalah ketetapan yang dibuat oleh diri kita sendiri dan untuk dilaksanakan oleh kita sendiri baik itu janji terhadap Allah maupun orang lain Semoga isi kandungan dalam Q.S Shad ayat 4144 dapat kita ambil dan kita aplikasikan dalam kehidupan sehari-sehari.

\section{REFERENSI}

Abdul Latif. 2009. Pendidikan Berbasis Nilai Kemasyarakatan. Bandung: Reflika Aditama.

Abu Al-Fida Muhammad Ali Ashobuni. 1986. Tafsir Ibnu Katsi. Jakarta: Gema Insani

Abudin Nata. 2010. Ilmu Pendidikan Islam. Jakarta: Prenada Media.

Ahmad Musthafa Al-Maraghi. 1993. Tafsir Al-Maraghi Jilid 23. Semarang: Toha Putra.

Ahmad Syadali dan Rofi'I. 1997. Ulumul Qur'an. Bandung: CV. Pustaka Setia

Ahmad Tafsir.1993. Metode Pengajaran Agama Islam. Bandung: Remaja Rosda Karya

Ahmad Tafsir. 2008. Filsafat Pendidikan Islami. Bandung: PT. Remaja Rosdakarya.

Hamka. 2015. Tafsir Al-Azhar, Depok: Gema Insani.

Hasbi Asy-Shiddieqy. 1980. Sejarah dan Pengantar Ilmu Al-Qur'an dan Tafsir. Jakarta: Bulan Bintang.

Muhammad Baqir Hakim. 2006. Ulumul Qur'an. Jakarta: Al-Huda.

M. Quraish Shihab. 2000. Tafsir Al-Misbah. Jakarta: Lentera Hati. 
M. Rasyid Ridha. Tafsir Al-Qur'an Al-Hakim, Tafsir Al-Manar Juz VII, Beirut: Dar Al-Fikr.

M. Sukardjo dan Ukim Komarudin. 2012. Landasan Pendidikan Konsep dan Aplikasinya, Jakarta: PT. Rajagrafindo Persada.

M. Suyudi. 2005. Pendidikan dalam Perspektif Al-Qur'an, Yogyakarta: Mikraj.

Manna' Khalil Al-Qathan. Studi Ilmu Al-Qur'an Terjemah Mudzakir

Omar Mohammad Al-Thoumi. 1979. Falsafah Pendidikan Islam. Jakarta: Bulan Bintang.

Ramayulis. 2009. Ilmu Pendidikan Islam, Jakarta: Kalam Mulia.

Rosihon Anwar. 1999. Sentuhan-Sentuhan Sufistik Penuntun Jalan Akhirat. Bandung: Pustaka Setia.

Salim, H. (1985). Sejarah 25 Nabi dan Rasul, Bandung: Makmur

Sudarto. 1995 . Metodologi Penelitian Filsafat. Jakarta: Raja Grafindo.

Sudirman. 1987. Ilmu Pendidikan. Bandung: Remaja Karya.

Sutarjo Adisusilo. 2014. Pembelajaran Nilai Karakter, Bandung: Rajawali Pers.

Undang Burhanudin. 2015. Modul Tafsir I dan Pembelajarannya, Bandung.

Zakiah Daradjat . 2009. Ilmu Pendidikan Islam, Jakarta: Bumi Aksara 